\title{
IDENTIFYING OBSTACLES AND DEFINING A STACK OF TYPICAL PROBLEMS RELATED TO MANAGING THE INNOVATION PROCESS IN THE METALLURGICAL INDUSTRY
}

\author{
${ }^{1}$ Jindra PETERKOVÁ, ${ }^{2}$ Katarzyna CZERNÁ \\ ${ }^{1}$ VSB - Technical University of Ostrava, Faculty of Economics Ostrava, Czech Republic, EU, \\ indra.peterkova@vsb.cz \\ ${ }^{2}$ VSB - Technical University of Ostrava, Faculty of Economics Ostrava, Czech Republic, EU, \\ katarzyna.czerna@vsb.cz
}

https://doi.org/10.37904/metal.2020.3641

\begin{abstract}
To ensure the effectiveness of the management of innovation activities, it is important to focus on the management of the innovation process and the identification of problems related to it. The innovation process begins with the generation of ideas and ends with their commercial use. The innovation process usually consists of phases such as generating invention, creating innovation and bringing innovation to the market. Recently, the emphasis has been placed on the learning phase, which serves to gather knowledge from completed projects and allows their use in the next generation of products. During the management of the innovation process in all its phases, problems arise that are important to identify and assign to the individual phases of the innovation process, respectively. define a stack of type problems. Identification of problems related to the management of the innovation process will be carried out through a questionnaire survey of 60 innovative companies in the Moravian-Silesian Region and 60 companies in the Silesian Voivodeship, but also from a statistical survey focused on the implementation of innovation activities. The aim is to identify differences in the approach to the implementation of the innovation process and the nature of the process in selected companies. Whether the innovation process is implemented on the basis of set steps resulting from experience from past innovation cases, or intuitively, without taking into account past innovation cases. At the same time, problems in the innovation process will be identified separately for companies classified according to CZ-NACE according to economic activity in the group / 24 / Manufacture of basic metals, metallurgical processing of metals, foundry and / 25 / Manufacture of metal structures and metal products, except machinery and equipment. Subsequently, they will be compared with other companies in the research sample through cluster analysis.
\end{abstract}

Keywords: Metallurgy, innovation, innovation process, cluster analysis

\section{INTRODUCTION}

The CZ-NACE 24 and the CZ-NACE 25 branches possess an important place in the manufacturing industry. The CZ-NACE 25 includes the manufacture of metal structures and metal products and is an important supplier of components for the assembly of finished products and equipment for companies operating in the engineering and automotive industries. The CZ-NACE 25 includes the production of metal products, while the material input to this branch is traditional metal semi-finished products produced in the CZ-NACE 24 branch. The given branch focuses on the production of basic metals, metallurgical processing of metals, and foundry. The steel industry in the Czech Republic, but also in the whole of Europe, is fighting for viability. Businesses in the metallurgical industry are well aware that without investment in research, development, and innovation, they will not be competitive and will disappear. The results of the statistical survey on innovation activities for 
the period 2016-2018 for enterprises belonging to CZ-NACE 24 and 25 showed that $49 \%$ of enterprises innovate and $51 \%$ do not. The most important market for companies implementing innovation activities is the national market $(51.7 \%)$. They mainly implement process innovations $(22.2 \%)$. Innovative processes are mainly developed in-house. At the same time, the implementation of innovation activities is associated with effective management, respectively with the management of individual steps of the innovation process. When managing the innovation process, problems arise. It is necessary to identify and assign them to the individual phases of the innovation process and then try to eliminate them. There are no statistical data on the nature of the innovation process and problems [1].

The paper aims to evaluate the innovation process, including obstacles in the implementation and identification of problems within the innovation process. Data for evaluation are obtained based on the author's research survey on a research sample of innovative companies in the Moravian-Silesian Region (MSR - 60) and the Silesian Voivodeship (60). At the same time, the research samples will include enterprises belonging to NACE 24 (Manufacture of basic metals, metallurgical processing, foundry) and 25 (Manufacture of fabricated metal products, except machinery and equipment) and will be evaluated based on selected criteria against other enterprises in research. sample. Also, based on the cluster analysis, differences like the innovation process will be defined, including the identification of the problem between companies belonging to sectors 24 and 25 compared to other companies in the research sample, especially for the Moravian-Silesian Region and Silesian Voivodeship.

\section{THEORETICAL AND METHODOLOGICAL BACKGROUND}

The innovation process begins with the generation of ideas and ends with their commercial use $[2,4]$. The defined phases of the innovation process are similar for most authors [3-6]. This is usually the phase of generating invention, creating innovation, and bringing innovation to the market. However, for the authors Tidd and Bessant [7], the innovation process also includes a learning phase, which serves to gather knowledge from completed projects and allows their use in the next generation of products. The description of activities related to the management of the innovation process will be based on the definition of the innovation process according to the authors Tidd and Bessant [7].

To map the nature of the innovation process and to identify problems, research survey is carried out through a questionnaire. The research survey is focused on a selected sample of innovative enterprises (MSR $60+$ SV 60), while from each sample the enterprises belonging to the NACE 24 and 25 branches are defined and compared with other enterprises in the sample. Cluster analysis is used to compare the results between enterprises belonging to NACE 24 and 25 and other enterprises in the research sample.

Cluster analysis can be applied to the examination of multidimensional data to classify a set of objects into several relatively homogeneous subsets, namely clusters $[8,9]$. Objects inside clusters should be as similar as possible and objects belonging to different clusters as different as possible. The basic rule for creating object clusters is the similarity between objects. For its measurements, an appropriate correlation measure, distance measure, or association measure can be used. Correlation and distance measures are used mainly for ratio data, while association measures are intended more for enumerated (nominal) data. Common measures of distance include Euclidean distance, Euclidean distance square, Manhattan distance (Hamming metric), generalized Minkovian metric, chord distance, and Mahalanobis metric. Common clustering methods include: nearest neighbour method - the clustering pair is selected according to the smallest distance; farthest neighbour method - the pair for clustering is selected according to the greatest distance; average distance method - based on the average distance of all objects in the $1^{\text {st }}$ cluster to all objects in the $2^{\text {nd }}$ cluster and Ward's method - in each step the increment of the sum of squares of deviations, created by merging them, is calculated for all pairs of deviations, and then the clusters are combined, which corresponds to the minimum value of this increment. Clustering by this method can be represented using a binary tree, a dendrogram. 


\section{RESULTS}

Based on the research on a sample of innovative companies in the Moravian-Silesian Region (60) and the Silesian Voivodeship (60), it was found that even though both regions are economically and culturally similar, there are differences in the way they develop innovative products and processes, in barriers and used innovation management models. On the contrary, in both regions, innovations play a crucial role in the corporate philosophy and mainly technical and product innovations are implemented. At the same time, enterprises belonging to NACE sectors 24 and 25 were singled out in the research samples and were evaluated based on selected criteria against other enterprises in the sample and compared through cluster analysis.

\subsection{Evaluation of enterprises in NACE 24 and 25 based on selected criteria}

The evaluation of Czech and Polish enterprises belonging to NACE 24 and 25 was carried out with regard to 5 criteria, namely the method of product development, obstacles in the implementation of the innovation process, the method of innovation, the nature of the innovation process, including the steps of innovation, see Table 1.

Table 1 Evaluation of enterprises in CZ-NACE 24 and 25 and in PL-NACE 24 and 25

\begin{tabular}{|c|c|c|c|c|c|}
\hline $\begin{array}{l}\text { Research } \\
\text { sample }\end{array}$ & $\begin{array}{l}\text { Product } \\
\text { development } \\
\text { method }\end{array}$ & Obstacles & $\begin{array}{l}\text { Way of innovation } \\
\text { implementation }\end{array}$ & $\begin{array}{l}\text { The character } \\
\text { of the } \\
\text { innovation } \\
\text { process }\end{array}$ & $\begin{array}{l}\text { Procedural steps } \\
\text { of the innovation } \\
\text { process }\end{array}$ \\
\hline $\begin{array}{l}\text { Branches } \\
\text { CZ-NACE } 24 \\
\text { and } 25\end{array}$ & $\begin{array}{l}\text { Own research } \\
\text { and development } \\
(57 \%)\end{array}$ & $\begin{array}{l}\text { Shortage of } \\
\text { employees } \\
(61 \%)\end{array}$ & $\begin{array}{l}\text { Innovations are } \\
\text { implemented on the } \\
\text { basis of procedural } \\
\text { steps }(66 \%)\end{array}$ & $\begin{array}{l}\text { Formalized } \\
\text { innovation } \\
\text { process (66 \%) }\end{array}$ & $\begin{array}{l}\text { Survey }(75 \%) \text {, } \\
\text { choice }(64 \%) \text {, } \\
\text { implementation } \\
(70 \%) \text {, learning } \\
(40 \%) .\end{array}$ \\
\hline $\begin{array}{l}\text { Total } \\
\text { research } \\
\text { sample }\end{array}$ & $\begin{array}{l}\text { Own research } \\
\text { and development } \\
(75 \%)\end{array}$ & $\begin{array}{l}\text { Shortage of } \\
\text { employees } \\
(79 \%)\end{array}$ & $\begin{array}{l}\text { Innovations are } \\
\text { implemented on the } \\
\text { basis of procedural } \\
\text { steps }(79 \%)\end{array}$ & $\begin{array}{l}\text { Formalized } \\
\text { innovation } \\
\text { process (83 \%) }\end{array}$ & $\begin{array}{l}\text { Survey }(76 \%) \text {, } \\
\text { choice }(55 \%) \text {, } \\
\text { implementation } \\
(76 \%) \text {, learning } \\
(50 \%) .\end{array}$ \\
\hline $\begin{array}{l}\text { Branches } \\
\text { PL- NACE } \\
24 \text { and } 25\end{array}$ & $\begin{array}{l}\text { Own research } \\
\text { and development } \\
(69 \%)\end{array}$ & $\begin{array}{l}\text { Low return on } \\
\text { investment } \\
(80 \%)\end{array}$ & $\begin{array}{l}\text { Innovations are } \\
\text { implemented on the } \\
\text { basis of procedural } \\
\text { steps }(79 \%)\end{array}$ & $\begin{array}{l}\text { Formalized } \\
\text { innovation } \\
\text { process (83 \%) }\end{array}$ & $\begin{array}{l}\text { Survey (88\%), } \\
\text { choice (76\%), } \\
\text { implementation } \\
(89 \%) \text {, learning } \\
(23 \%) .\end{array}$ \\
\hline $\begin{array}{l}\text { Total } \\
\text { research } \\
\text { sample }\end{array}$ & $\begin{array}{l}\text { Cooperation with } \\
\text { research } \\
\text { institutions (43\%) }\end{array}$ & $\begin{array}{l}\text { Lack of } \\
\text { finance } \\
(77 \%)\end{array}$ & $\begin{array}{l}\text { Innovations are } \\
\text { implemented in }\end{array}$ & $\begin{array}{l}\text { Non-formalized } \\
\text { innovation } \\
\text { process (77 \%) }\end{array}$ & $\begin{array}{l}\text { Survey (83\%), } \\
\text { choice }(53 \%) \text {, } \\
\text { implementation } \\
(94 \%) \text {, learning } \\
(5 \%) .\end{array}$ \\
\hline
\end{tabular}

\section{Source: own research}

The evaluation shows that Czech companies in the CZ-NACE 24 and 25 sectors are implemented in the same way as other companies in the research sample, mainly on the basis of their own research and development, and the main obstacle to the implementation of innovations is staff shortages. At the same time, innovations are implemented on the basis of procedural steps and the innovation process has a formalized character. It was also found that less weight for learning from the innovation process is placed in enterprises in CZ-NACE 24 and 25 than in enterprises in the total research sample. In contrast, for enterprises in PL-NACE 24 and 25, differences were found in all evaluation criteria compared to other enterprises in the sample. Polish companies 
in the PL-NACE sector implement innovations mainly on the basis of their own research and development, the main obstacles include low investment return, innovations are implemented on the basis of steps, the innovation process is formalized and they place more emphasis on the learning phase within the innovation process than other enterprises in the sample. In contrast, for other Polish companies in the sample, innovations are implemented on the basis of cooperation with research institutions, the main obstacle to the implementation of innovations is the lack of funding, innovations are implemented intuitively and the innovation process is informalized.

Based on the research survey, the problems that most often appear in individual phases of the innovation process (research, choice, implementation, learning) were also identified, see Table 2.

Table 2 Problems in individual phases of the innovation process

\begin{tabular}{|c|c|c|c|c|}
\hline \multirow{2}{*}{$\begin{array}{l}\text { Research } \\
\text { sample }\end{array}$} & \multicolumn{4}{|c|}{ Problems in individual phases of the innovation process } \\
\hline & Survey problems & $\begin{array}{l}\text { Problems with } \\
\text { selection }\end{array}$ & $\begin{array}{l}\text { Problems with } \\
\text { implementation }\end{array}$ & Problems with learning \\
\hline $\begin{array}{l}\text { CZ-NACE } \\
24 \text { and } 25\end{array}$ & $\begin{array}{l}\text { No innovation } \\
\text { forecasting } \\
(47 \%) \text {, lack of } \\
\text { data to map the } \\
\text { environment } \\
(39 \%)\end{array}$ & $\begin{array}{l}\text { Lack of funding for } \\
\text { implementation } \\
(21 \%) \text {, lack of } \\
\text { knowledge for } \\
\text { selection }(20 \%)\end{array}$ & $\begin{array}{l}\text { Long-term } \\
\text { implementation } \\
(56 \%) \text {, lack of } \\
\text { employee } \\
\text { experience (38 \%) }\end{array}$ & $\begin{array}{l}\text { No routines for the } \\
\text { innovation process } \\
(39 \%) \text {, no formalized } \\
\text { steps (20\%) }\end{array}$ \\
\hline $\begin{array}{l}\text { Total } \\
\text { research } \\
\text { sample }\end{array}$ & $\begin{array}{l}\text { Lack of knowledge } \\
\text { from market } \\
\text { research }(46 \%) \text {, } \\
\text { bad market } \\
\text { research }(33 \%)\end{array}$ & $\begin{array}{l}\text { Insufficient demand } \\
(48 \%) \text {, lack of } \\
\text { workers ( } 41 \%)\end{array}$ & $\begin{array}{l}\text { Long-term } \\
\text { implementation } \\
(48 \%) \text {, lack of } \\
\text { employee } \\
\text { experience (45\%) }\end{array}$ & $\begin{array}{l}\text { No evaluation of the } \\
\text { steps implementation } \\
\text { ( } 28 \%) \text {. No evaluation } \\
\text { of the implementation } \\
\text { of innovation ( } 28 \%)\end{array}$ \\
\hline $\begin{array}{l}\text { PL-NACE } \\
24 \text { and } 25\end{array}$ & $\begin{array}{l}\text { No forecasting of } \\
\text { innovations } \\
\text { ( } 78 \% \text { ), lack of } \\
\text { data to map the } \\
\text { environment } \\
(76 \%)\end{array}$ & $\begin{array}{l}\text { Lack of funding for } \\
\text { implementation } \\
(80 \%) \text {, insufficient } \\
\text { technical background } \\
(48 \%)\end{array}$ & $\begin{array}{l}\text { Low product } \\
\text { profitability }(79 \%) \text {, } \\
\text { long-term } \\
\text { implementation } \\
(57 \%)\end{array}$ & $\begin{array}{l}\text { No evaluation of the } \\
\text { implementation of } \\
\text { innovation ( } 89 \%) \text {, no } \\
\text { routines for the } \\
\text { innovation process } \\
(69 \%)\end{array}$ \\
\hline $\begin{array}{l}\text { Total } \\
\text { research } \\
\text { sample }\end{array}$ & $\begin{array}{l}\text { No innovation } \\
\text { forecasting } \\
(82 \%) \text {, bad } \\
\text { market research } \\
(68 \%)\end{array}$ & $\begin{array}{l}\text { Insufficient demand } \\
\text { (73\%), lack of } \\
\text { funding for } \\
\text { implementation } \\
(70 \%) \text {, }\end{array}$ & $\begin{array}{l}\text { Low product } \\
\text { profitability }(86 \%) \text {, } \\
\text { no customer interest } \\
(54 \%)\end{array}$ & $\begin{array}{l}\text { No evaluation of the } \\
\text { implementation of } \\
\text { innovation }(71 \%) \text {, no } \\
\text { routines for the } \\
\text { innovation process } \\
(66 \%)\end{array}$ \\
\hline
\end{tabular}

Source: own research

When identifying problems in individual phases of the innovation process for companies in CZ-NACE 24 and 25 , the main problem in the survey phase is the lack of forecasting, in the decision-making phase the problem is lack of funds, in the implementation phase the main problem is long-term implementation and in the learning phase the problem of non-existent routines for the innovation process. The same identified problems were found for enterprises in the PL-NACE sector in the survey phase and the decision selection phase. The differences are in the implementation phase, where the main problem is low product profitability and in the learning phase, where the main problem is the lack of evaluation of innovation implementation. At the same time, there are differences in identifying problems for enterprises in the NACE sector, both in the Czech Republic and in Poland, compared to other enterprises in research samples. 


\subsection{Comparison of enterprises in NACE 24 and 25 with other enterprises in the research sample}

The comparison of enterprises in NACE 24 and 25 with other enterprises in the research sample is performed through cluster analysis. Within the cluster analysis, two criteria were used: the principle of the method of implementation of the innovation process, which can be implemented intuitively or based on formalized process steps, and then the existing problems in the individual phases of the innovation process. The cluster analysis was carried out separately for enterprises in CZ-NACE 24 and 25 to other enterprises in MSR, see Figure 1, and for enterprises in PL-NACE to other enterprises in Silesian Voivodeship, see Figure 2. The obtained results are captured using dendrograms.

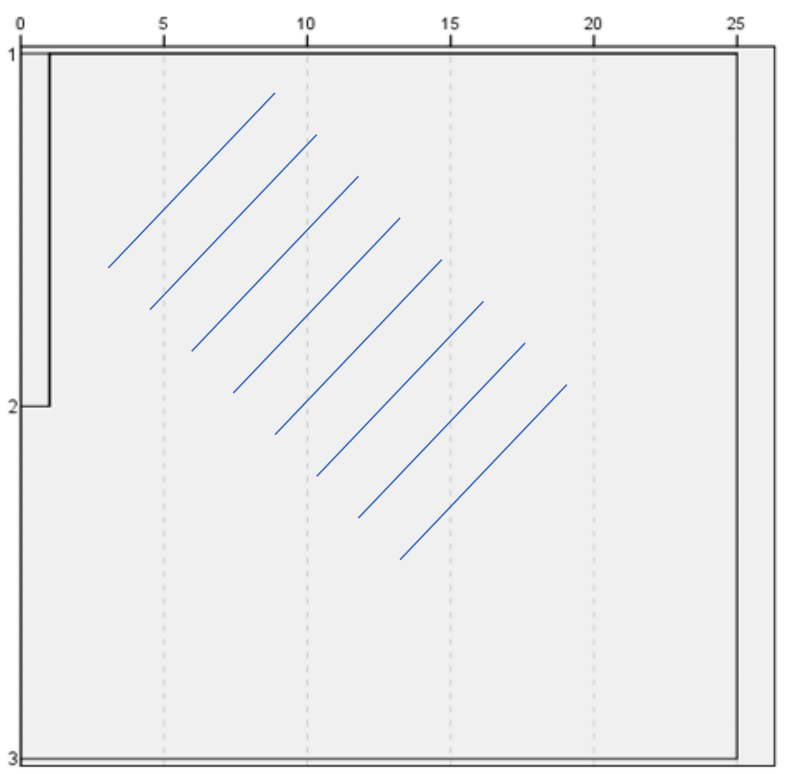

Figure 1 Dendrogram for CZ-NACE 24 and 25 and other enterprises in the research sample

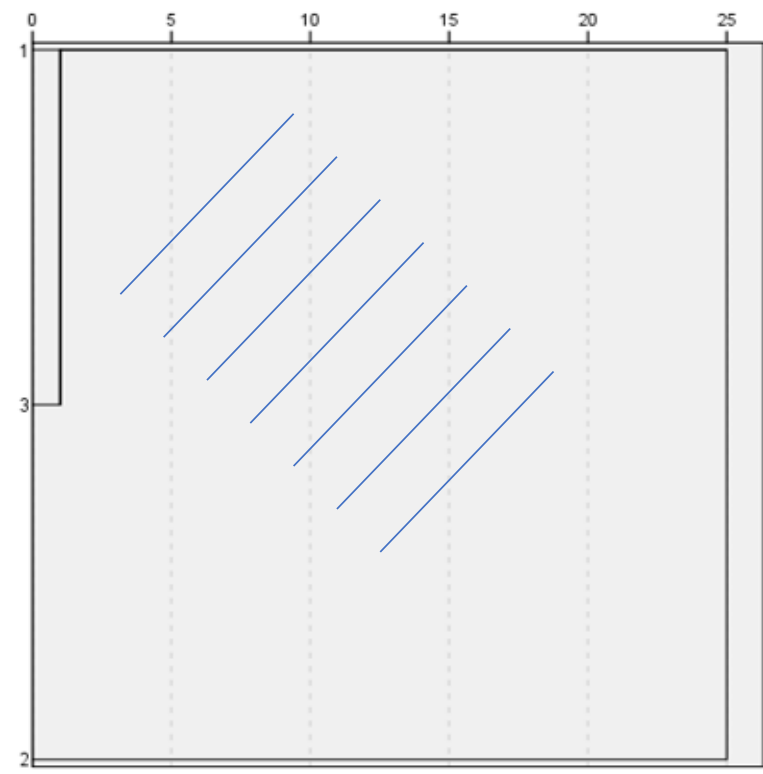

Figure 2 Dendrogram for PL-NACE 24 and 25 and other enterprises in the research sample

In the dendrogram, see Figure 1, two clusters are created (one of them is always marked by hatching). The first cluster consists of enterprises from CZ-NACE 25 and all other enterprises in MSR without enterprises in CZ-NACE 24. The following characteristics are common to this cluster: lack of staff, lack of knowledge from marketing research, insufficient demand, long-term implementation of innovations, and the problem consisting in the evaluation of innovations. The second cluster consists only of enterprises in the CZ-NACE 24 sector. Common characteristics for this cluster include problem in forecasting innovation, lack of funding for implementation, the problem with employee experience, non-existent routines for innovation.

Two clusters are created in the dendrogram, see Figure 2. The first cluster consists of companies from PLNACE 24 and 25. The following characteristics are common to this cluster: the highest obstacle in the innovation process is the return on investment, they focus on formalizing the innovation process, they have their department of research and development in companies. The second cluster consists of all other enterprises in the Silesian Voivodeship except for enterprises in the PL-NACE 24 and 25 sectors. The main common characteristics include the problem of lack of innovation forecasting, low product profitability, and non-existent knowledge base.

\section{CONCLUSIONS}

Branches CZ-NACE 24 and CZ-NACE 25 are technologically interconnected. Concerning the technologies used, they are part of the MEDIUM LOW-TECH sector. This research survey was carried out, based on obtained primary data on innovative enterprises in the Moravian-Silesian Region and the Silesian Voivodeship, 
including enterprises from NACE 24 and 25 in the Czech Republic and Poland. There was an appreciation of enterprises in CZ-NACE 24 and 25 against other enterprises in the Moravian-Silesian Region and an appreciation of enterprises in PL-NACE 24 and 25 against other enterprises in Silesian Voivodeship concerning five criteria: method of product development, obstacles, method of implementation innovation, the nature of the innovation process and the steps of the innovation process. It was found that the nature of the criteria for enterprises in CZ-NACE 24 and 25 is the same as the nature of the criteria for other enterprises in MSR. In contrast, the nature of the criteria for enterprises in the PL-NACE sector is different from the nature of the criteria for other enterprises in the Silesian Voivodeship. At the same time, the main problems within the individual phases of the innovation process for companies in the CZ-NACE sector were identified, namely: there is no forecasting of innovations, lack of funds for implementation, long-term implementation, non-existent routines for the innovation process. The main problems were also identified for companies in the PL-NACE sector, namely: there is no forecasting of innovations, there is a lack of funds for implementation, low profitability of the product, there is a lack of evaluation of the implementation of innovations. Subsequently, enterprises in the NACE 24 and 25 sectors were compared with other enterprises, especially for the MoravianSilesian Region and the Silesian Voivodeship using cluster analysis. The results obtained vary from country to country and are captured using dendrograms.

\section{ACKNOWLEDGEMENTS}

This article was created with the financial support of the Student Grant Competition EkF, VŠB-TU Ostrava within project "SP2020/107" Specification of typical business management problems, including solutions and identification of approaches to the creation of business models in selected innovative companies in the Czech Republic ".

\section{REFERENCES}

[1] PETERKOVÁ, J., WOZNIAKOVÁ, J. The Czech Innovative Enterprise. Journal of Applied Economics Sciences. 2015, vol. 10, issue: 2, pp. $243-252$. ISSN 1843-6110.

[2] VEBER, J. et al. Managing Innovation. Praha: Management Press, 2016.

[3] KOŠTURIAK, J., CHAL' J. Inovace, vaše konkurenční výhoda!. Brno: Computer Press, 2008.

[4] HERZOG, P. Open and Closed Innovation: Different Cultures for Different Strategies. Wiesbaden: Springer Gabler, 2011.

[5] KASSAY, Š. Podnik a podnikanie: Interné procesy. Bratislava: VEDA, 2013.

[6] ONDRA, M. ŠKAROUPKA, D., RAJLICH J. Innovating product appearance within brand identity. International Journal of Innovation Science. 2017, vol. 9, issue: 2, pp.153-169. https://doi.org/10.1108/IJIS-12-2016-0055.

[7] TIDD, J., BESSANT, J. Managing Innovation: Integrating Technological, Market and Organizational Change. 5th Edition. Chichester: Wiley, 2013.

[8] CHARRY, K., COUSSEMENT, K., DEMOULIN, N., HEUNVICK, N. The Ward's minimum variance method is the most commonly used method in management. Marketing Research with IBM SPSS Statistics. 2016, p. 71.

[9] ŘEZÁNKOVÁ, H., HÚSEK, D., SNÁŠEL V. Shluková analýza dat. Praha: Professional Publishing, 2009. 